\title{
THE TOXIC FACTORS IN EXERIMENTAL TRAUMATIC SHOCK. VI. THE TOXIC INFLUENCE OF THE BACTERIAL FLORA, PARTICULARLY CLOSTRIDIUM WELCHII, IN EXU- DATES OF ISCHEMIC MUSCLE ${ }^{1}$
}

\author{
By A. POPE, P. C. ZAMECNIK, J. C. AUB, A. M. BRUES, R. J. DUBOS, \\ I. T. NATHANSON, AND A. L NUTT \\ (From the Medical Laboratories of the Collis P. Huntington Memorial Hospital of \\ Harvard University at the Massachusetts General Hospital, and the \\ Department of Comparative Pathology and Tropical Medicine, \\ Harvard Medical School, Boston, Massachusetts)
}

(Received for publication April 9, 1945)

As has been shown in previous reports from this laboratory $(10,25,75)$, toxic effects resembling traumatic shock have been observed following the intravenous injection of fluids exuding from dog muscles after prolonged ischemia.

The fact that 28 per cent of these fluids were highly toxic, whereas the remainder seemed harmless, strongly suggested that their toxic effects were not due to the presence of intracellular substances lost as the result of cell damage (70). For the same reason, it appeared doubtful that the occasional toxic effects were caused by breakdown products of muscle cell constituents resulting from ischemia, since the experimental conditions were all approximately identical. Attention has been directed, therefore, to the one constituent of - these fluids which was obviously highly variable, namely, the bacterial flora.

Another bit of indirect evidence pointed in this direction. On several occasions, dog muscle tissue was excised and minced with sterile precautions and incubated in sterile dog plasma at $37^{\circ} \mathrm{C}$., for 5 hours. The plasma was then separated by centrifugation and injected intravenously into recipient dogs. Such material was invariably toxic, rapidly producing a shock-like state and death, and it was always infected with micro-organisms which on direct smear were seen to be large gram-positive rods. However, if a mixture of blended dog muscle and plasma were sterilized by passage through a Seitz filter before incubation,

${ }^{1}$ This is reprint No. 610 of the Cancer Commission of Harvard University.

The work described in this paper was done under a contract, recommended by the Committee on Medical Research, between the Office of Scientific Research and Development and the Massachusetts General Hospital. it never exhibited toxic properties when administered to a recipient animal.

\section{EXPERIMENTAL}

Our method of muscle ligation and muscle exudate collection has been described (14). All operative procedures were carried out under sodium pentobarbital anesthesia and with the customary aseptic precautions.

Amounts of fluid exuding from the 2 muscle groups in a 5-hour period after release of ligatures varied in these experiments from 2 to $17 \mathrm{ml}$. per $\mathrm{kgm}$. body weight of the donor dog. The composition of this fluid and its shock-producing effect when administered intravenously have been described in detail $(70,75)$.

Practically all of the muscle exudates contained bacteria as demonstrated by direct gram stain. The amount of bacterial contamination in most of these fluids was determined by quantitative culture methods. Five-tenths $\mathrm{ml}$. of the fluid to be tested were mixed with $4.5 \mathrm{ml}$. of beef broth, and 3 successive 1:10 dilutions in broth were made. Two blood agar plates were then divided into quadrants and a loopful (approximately 1/ $\mu 1$.) of each dilution was streaked onto 1 quadrant of each plate. One of these was incubated aerobically and the other in an atmosphere of 5 per cent $\mathrm{CO}_{2}$ in nitrogen. After 36 hours of incubation at $37^{\circ} \mathrm{C}$., differential colony counts were made and identification of the bacterial species present was undertaken. Colony counts were multiplied by the appropriate factors to give numbers of viable bacteria per $\mathrm{ml}$. of original fluid, and these were checked qualitatively with observations on direct smears. Clostridia were isolated and cultivated from various fluids.

In an attempt to reproduce at will the picture of toxicity following fluid injection, 2 strains of Clostridia perfringens thus isolated were used in 3 experiments. In these experiments, at the time of muscle ligation, 2 to 5 $\mathrm{ml}$. of a broth culture of these organisms were injected into each of the 2 muscle groups; after the period of occlusion of the blood supply the ligatures were released as usual and fluid collected. These have been termed "reinforced" fluids. Bacterial counts were made on the first fluid obtained from each leg, on a final sample drain- 
ing off at the end of a 6-hour period, and from the pooled fluid.

A series of dog muscle biopsies have been done in an effort to discover whether clostridia can be grown from samples of dog muscle obtained under aseptic precautions. After preparing the skin in the same way as described for the operative ligation of muscles, the skin was incised and the edges retracted. The subcutaneous fascia was then incised and retracted with a fresh set of sterile instruments, and samples of muscle (about 1 gram) were excised, using a third set of instruments. In other cases, the skin was seared either by a hot scalpel or electrocautery. The remainder of the procedure was accomplished by means of electro-surgical technique. Samples of rectus and sartorius muscle were taken by both these methods. Biopsies of skin were also removed after the usual preparation including a very strong solution of iodine. All biopsy specimens were placed at once into meat infusion broth and incubated in an atmosphere of 5 per cent $\mathrm{CO}_{2}$ in nitrogen.

\section{RESULTS}

In spite of the aseptic precautions, the fluid exudates collected after muscle ischemia have all contained bacteria. In most wounds, the body takes care of such contaminations, but traumatized anoxic tissues offer excellent media for growth and toxin formation. It appears, therefore, likely that traumatizing experiments on dogs must in general be complicated by contamination with bacteria which, in most observations on shock, would have time to exert a toxic influence.

Organisms cultured from fluids. Aerobic cultures were made in 30 instances. One of these cultures was made from a pool of 2 fluids used for injection and another from a pool of 9 fluids, so that 39 exudates are represented. Anaerobic cultures were made of 19 separate fluids, all of which are also represented in the figures given for aerobic flora. Table I shows the results of these cultures, and it will be noted that staphylo-

TABLE I

Micro-organisms identified in muscle exudates

\begin{tabular}{l|c|c|c}
\hline \multicolumn{1}{c|}{ Organism } & $\begin{array}{c}\text { Number } \\
\text { of times } \\
\text { identified }\end{array}$ & $\begin{array}{c}\text { Number } \\
\text { of cultures } \\
\text { made }\end{array}$ & $\begin{array}{c}\text { Percentage } \\
\text { of fluids } \\
\text { present }\end{array}$ \\
\hline Clostridia & 13 & 19 & 72 \\
Staph. albus & 23 & 30 & 78 \\
Staph. aureus & 8 & 30 & 27 \\
B. subtilis & 9 & 30 & 30 \\
Coliform bacilli & 7 & 30 & 23 \\
M. tetragenes & 4 & 30 & 13 \\
Streptococci & 2 & 30 & 7 \\
Unidentified & 2 & 30 & 7 \\
\hline
\end{tabular}

cocci and clostridia are the most common contaminants, each having been cultivated from the great majority of fluids. Where clostridia were cultured to determine type, as well as morphology, $C l$. perfringens was obtained.

Bacteria in relation to toxicity. On 19 separate fluids, quantitative bacterial counts were made by both aerobic and anaerobic culture, and the toxicity of 18 of these fluids was determined by intravenous infusion into recipient dogs. In 5 cases, 2 fluids were pooled for assay purposes.

TABLE II

- Muscle exudates: correlation of properties with number of Clostridia

\begin{tabular}{c|c|c|c|c|c}
\hline \hline $\begin{array}{c}\text { Donor } \\
\text { dog } \\
\text { number }\end{array}$ & $\begin{array}{c}10^{\circ} \times \\
\text { Clost./ml. }\end{array}$ & $\begin{array}{c}10 \% \\
\times \text { Staph./ } \\
\text { ml. }\end{array}$ & $\begin{array}{c}\text { Fluid } \\
\text { output } \\
\text { ml./kgm. }\end{array}$ & $\begin{array}{c}\text { Recipient } \\
\text { dog } \\
\text { number * }\end{array}$ & Toxicity \\
\cline { 2 - 5 } 166 & 0.001 & 1.0 & 7 & 167 & 0 \\
$217-218$ & 0.01 & $2.8-3.0$ & $8-6$ & 219 & 0 \\
$221-222$ & 0.03 & $0-0$ & $5-4$ & 223,224 & 0 \\
$226-227$ & 0.14 & $0.06-0$ & $5-3$ & 228,233 & 0 \\
$214-215$ & 0.17 & $0.09-0$ & $3-10$ & 216 & 0 \\
$186-187$ & 2.7 & $0.5-6.0$ & $15-6$ & 188 & 0 \\
177 & 2.8 & 0.8 & 14 & 179 & 0 \\
168 & 3.0 & 0.6 & 17 & 169 & 0 \\
181 & 5.0 & 2.4 & 16 & 183 & + \\
171 & 35.0 & $+* *$ & 17 & 174,175 & 0 \\
176 & 160.0 & 28 & 8 & 178 & 0 \\
180 & 500.0 & 40 & 16 & 182 & + \\
172 & 750.0 & $+* *$ & 13 & 173 & + \\
\hline
\end{tabular}

* The average fluid output of this series of animals is approximately $9 \mathrm{ml}$. per $\mathrm{kgm}$. In a larger series the average output was $12 \mathrm{ml}$. per kgm.

** Staphylococci present but not quantitated.

Table II shows the results. It can be seen that the fluids with relatively low bacterial counts were always non-toxic; the 3 toxic fluids were included in the $\mathbf{5}$ highest clostridial counts. Staphylococcal counts correlated slightly less well with toxicity, but there was considerable correlation between the 2 organisms. There also appears to be some correlation between the bacterial counts and the amounts of fluid produced.

Growth and toxin production "in vivo." In 7 instances, data are available showing the increase in bacterial content of fluid obtained during the 6-hour period after release of ligatures. Cultures and colony counts were made on the first fluid and again on fluid accumulating at the end of the period. The results, as shown in Table III, demonstrate the magnitude of the increase. Since many of the initial counts were too low to be established quantitatively under the conditions 
used (i.e. below 10,000 per $\mathrm{ml}$.), they have been taken as $10^{4}$ per $\mathrm{ml}$. for the purpose of obtaining a figure representing the average of the increments. The calculated mean increment is, therefore, a minimum value. It is seen that there is greater than 1000-fold increase in the concentration of viable clostridia and staphylococci during the 6-hour period following release of the constricting band. Assuming a generation time of approximately 30 minutes, this rapid increase indictates that multiplication of clostridia must have started immediately, as soon as ischemia provided satisfactory anaerobic conditions for growth.

TABLE III

Increase of bacterial counts from initial to terminal fluids

\begin{tabular}{c|c|c|c|c}
\hline \hline \multirow{2}{*}{ Dog } & \multicolumn{2}{|c|}{ Clostridia } & \multicolumn{2}{|c}{ Staphylococci } \\
\cline { 2 - 5 } & Initial & Terminal & Initial & Terminal \\
\hline 176 & $<10^{4}$ & $1.6 \times 10^{8}$ & $<10^{4}$ & $2.8 \times 10^{7}$ \\
177 & $4 \times 10^{4}$ & $2.8 \times 10^{6}$ & $<10^{4}$ & $2.5 \times 10^{6}$ \\
180 & $2.5 \times 10^{5}$ & $1.0 \times 10^{9}$ & $2.2 \times 10^{5}$ & $1.0 \times 10^{8}$ \\
181 & $<10^{4}$ & $3.0 \times 10^{7}$ & $<10^{4}$ & $1.0 \times 10^{7}$ \\
186 & & & $6 \times 10^{4}$ & $2.5 \times 10^{6}$ \\
187 & $10^{4}$ & $6 \times 10^{4}$ & $<10^{4}$ & $2.5 \times 10^{7}$ \\
222 & & & \\
Average & $6.4 \times 10^{4}$ & $2.4 \times 10^{8}$ & & \\
\hline
\end{tabular}

Factor of

difference:

(By average

of increments

(By increment

$4 \times 10^{3}$

$11 \times 10^{2}$

of averages)

$4 \times 10^{3}$

$5 \times 10^{2}$

Reinforced fluids. In the case of fluids from muscles which, at the time of ligation, received injections of cultures of bacteria ( $\mathrm{Cl}$. perfringens) isolated from earlier experiments, extremely toxic exudates were obtained in comparison with those collected in routine experiments. The 3 fluids in this series, when injected intravenously, uniformly produced a shock-like picture terminating in death in 8 instances. In these cases, $5 \mathrm{ml}$. per $\mathrm{kgm}$. (or approximately onethird of the dose used in the earlier experiments) were given intravenously, and in all cases marked hemolysis was observed in the bloods of the recipients at the time of death. In 3 of the 8 experiments, bacteria had been removed by filtration through a Chamberland candle in 1 case and by centrifugation in the other 2 . Washed bacteria obtained by centrifugation were used in 2 experiments and produced no obvious effect except hyperthermia $\left(41^{\circ}\right.$ and $42^{\circ} \mathrm{C}$., respectively). In 1 further experiment, a lethal amount of reinforced fluid was injected along with $5 \mathrm{ml}$. polyvalent gas gangrene antitoxin (Lederle's) with complete protection against the effects of the fluid. Thus, the effects of the reinforced fluids are due to the presence of an exotoxin which is neutralized by gas gangrene antitoxin.

Increases in bacterial content and toxin concentration during the collection period were noted. Tests were made on the first fluid, the last fluid obtained at the end of 6 hours, and the pool of the total fluid obtained. In the case of 1 of these experiments, in addition to bacterial counts, toxicity was determined as the volume of fluid containing 1 mouse m.l.d. There was a 300 -fold increase in bacterial count and at least a 10-fold increase in the toxin concentration during the 6 hours after release of ligatures. When a $10 \mathrm{ml}$. culture was injected into the muscles at the time of ligation, the injected culture contained in all 100 mouse m.l.d. (L.D. 100) of toxin; following release of the muscle ligature, $270 \mathrm{ml}$. of fluid exuded from the muscle containing 1350 m.l.d. of toxin. It may be assumed that additional toxin was present in the muscles at the end of this period. Thus, the anoxic muscle in vivo has been shown to be a good medium for multiplication and toxin production by toxigenic clostridia.

Anaerobic cultures of biopsy specimens. In 11 of 13 intact dogs from which muscle biopsies were obtained, clostridia were grown from at least 1 muscle specimen, and they were cultivated in 13 instances out of a total of 25 such specimens ( 0.5 to 1 gram of tissue). Thus, clostridia were obtained from 85 per cent of the dogs whose muscles were biopsied. In addition, 36 per cent of the muscle specimens yielded coliform organisms and 8 per cent of them staphylococci.

In 2 dogs, all of 5 cultures of surgically prepared skin were positive for clostridia, and 1 from each dog showed the presence of staphylococci, coliform organisms, and diphtheroids. These data suggest that organisms of the gas gangrene group are common inhabitants of dog skin, where they presumably exist as spores, and are exceedingly readily introduced into the underlying tissues during operative procedures. The possibility that they are normal inhabitants of dog muscle in some instances is not ruled out. 
Anaerobic cultures were also made of muscle specimens obtained from 7 rats; 1 of these cultures yielded clostridia, another yielded a culture of gram-positive cocci, and the remainder were sterile.

Eighteen cultures were made of specimens of human muscle obtained from various elective operative procedures. ${ }^{1}$ In no case were clostridia grown from these specimens although staphylococci were obtained in 10 cases.

Identity of organisms. Clostridia obtained from muscle exudates and from dog biopsy specimens were identified as $\mathrm{Cl}$. perfringens in the following way.

Anaerobic cultures (in broth and on agar media) of muscle extracts and from dog biopsy specimens yielded large numbers of organisms which were identified as $\mathrm{Cl}$. welchii (perfringens) on the following grounds.

The colonies and broth cultures were found to consist of rods approximately $1 \mu$ in width and varying from 3 to $10 \mu$ in length. Very young organisms were frankly gram-positive but became gram-negative within 24 to 36 hours, all intermediate degrees of intensity of staining being observed in 1 given culture according to its age.

Spores were very rarely encountered and in particular could not be detected in sugar media.

The stormy fermentation of litmus milk and other fermentation reactions were typical of $\mathrm{Cl}$. welchii. Gelatin was liquified but no digestion of serum was observed.

The colonies were either smooth or rough, hemolytic or non-hemolytic ( $\beta$ hemolysis). The fact that these different colonial types could all be derived from 1 single colony isolated upon aging of the culture indicates that they were due to bacterial dissociation rather than being representatives of different bacterial species.

The cultures grown in ordinary glucose broth were only a little toxic for mice (MLD $0.1 \mathrm{ml}$.). Toxicity could be much increased by growing the organism in meat media containing 0.5 per cent glucose or in media specially devised for the production of Welch toxin (MLD $0.001 \mathrm{ml}$.). ${ }^{2}$ The toxin could be neutralized by Welch antitoxin.

1 We are indebted to Dr. Carroll B. Larson for the bulk of these specimens.

2 This toxin was supplied by Dr. A. Pappenheimer, Jr.

\section{DISCUSSION}

The presence of bacteria of the gas gangrene group in normal dog muscle has been reported $(87,88)$, and both our studies and the confirmatory one of Cope and Langohr (unpublished data) have indicated that such organisms may be normal inhabitants of dog muscle; but it is more likely that they are introduced during operative manipulations, since they appear to be such frequent contaminants of $\mathrm{dog}$ skin. In all probability, they exist in skin as spores resistant to the usual methods of surgical preparation. In the $\mathrm{dog}$, therefore, gas bacilli are potential contaminants of artificially-traumatized or surgicallytreated tissues, and all experimental procedures which tend to result in ischemia and anoxia would produce conditions extremely favorable for their multiplication and toxin formation.

It should be emphasized, also, that from both biopsy material and "sterile" collected exudates from ischemic muscles, other microorganisms than clostridia, especially staphylococci and bacilli of the coliform group, have been frequently cultivated. The creation of damaged and relatively ischemic tissue tends to promote the growth of many types of pathogens, especially anaerobes, and among the commonly contaminating organisms are included several species capable of producing powerful exotoxins $(89,90)$. The ready accessibility of clostridia, the fact that conditions for their growth and toxin production are optimal, and the potency of their characteristic toxins make it important to investigate the rôle which such bacteria might play in the sequence of changes that constitute the syndrome of traumatic shock.

The toxins of several species of bacteria have been shown to have specific pharmacologic effects on the circulation with certain features in common with the classical changes of shock. Notable examples of these are the exotoxins of gram-negative bacilli $(89,90)$. The production of hemolysis and death in rabbits by the intravenous administration of Welch bacillus toxin has been reported (91), and the action of this toxin has been further described (92). Experiments in this laboratory with purified $\mathrm{Cl}$. perfringens and $\mathrm{Cl}$. oedematiens toxins have confirmed these results in dogs and demonstrated both local and generalized toxic effects of these agents on the circulatory system. 
These facts make it clear that the element of bacterial infection and its consequences are factors that must be taken into consideration in physiologic experiments which continue for longer than a few hours. Particularly in experiments on traumatic shock in which large areas of damaged and ischemic tissue are produced, the rôle of bacterial products in contributing towards the clinical outcome cannot be ignored. Interpretation of the results of experiments in which parenteral administration of various extracts of normal and traumatized tissues is made should involve consideration of the bacterial factor (93). This has been recognized and it has been shown that bacteria-free extracts of these types are without physiologic effects (65).

The possible rôle of micro-organisms in the genesis of traumatic shock following the injury of men in battle remains to be evaluated. Although human muscle biopsy specimens have been, in our experience, generally sterile, wounds sustained under battle conditions are usually contaminated with many species of bacteria, and the gas bacillus ranks high in its incidence in war wounds $(94,95)$. Certainly in many of the latter, conditions must be very favorable for the multiplication of such contaminants, and it is conceivable that sub-clinical amounts of highly toxigenic strains of bacteria, especially of the gas gangrene group, might produce sufficient quantities of toxin to be a factor in the development of circulatory failure, either by promoting loss of vascular fluid at the site of trauma or by acting generally on the cardio-vascular system. That the former may be a not insignificant effect in the case of the Welch bacillus toxin has been suggested (96). The irreversibility of the shock-like state produced by the intravenous administration of $\mathrm{Cl}$. perfringens and $\mathrm{Cl}$. oedematiens toxins (unpublished data) indicates that the production of toxins of these types in contaminated wounds can play a significant rôle in subsequent development of "irreversible" shock.

These considerations and especially the urgency of elucidating the pathogenesis of irreversible peripheral circulatory failure make it important to study human cases of traumatic shock from the point of view of the bacteriology of their wounds in order to determine what counterpart the findings reported in this paper have in clinical shock.

\section{SUMMARY}

The bacterial flora of ischemic canine muscle exudates has been investigated. Clostridium perfringens and Staphylococcus albus have been recovered from most of these exudates in widely varying concentrations. The clostridia have been shown to multiply and produce toxin in ischemic muscle, the multiplication starting as soon as ischemia provided satisfactory anaerobic conditions for growth. They are present in many biopsy specimens of normal dog muscle obtained with the use of rigid surgical techniques of skin sterilization and sterile handling of specimens. Clostridia are not present in normal human muscle.

Evidence has been obtained indicating a correlation between the toxicity of the fluids as administered to recipient dogs and their bacterial content. We think this bacterial contamination is the source of a "toxic factor" in experimental shock. Bacterial infection and its consequences must be taken into consideration in physiological experiments, particularly in those involving injury to tissue, even where performed by surgical methods.

The possible relation of clostridial infection to human wound shock remains to be elucidated. The frequent contamination of war wounds with these organisms indicates the importance of such an evaluation.

We wish to acknowledge the painstaking technical assistance of Mr. Fred Mapplebeck in caring for animals and carrying out many experimental procedures described in this series of papers.

\section{BIBLIOGRAPHY}

\section{Papers I to VI}

1. Cannon, W. B., and Bayliss, W. M., Note on muscle injury in relation to shock. Reports of the Special Investigation Committee on Surgical Shock and Allied Conditions. Medical Research Committee, London, 1919, p. 19.

2. Best, C. H., and Solandt, D. Y., Studies in experimental shock. Canad. M. A. J., 1940, 43, 206.

3. Swingle, W. W., Remington, J. W., Kleinberg, W., Drill, V. A., and Eversole, W. J., Experimental study of tourniquet as method for inducing circulatory failure in dog. Am. J. Physiol., 1942, 138, 156.

4. Duncan, G. W., and Blalock, A., The uniform production of experimental shock by crush injury: possible relationship to clinical crush syndrome. Ann. Surg., 1942, 115, 684. 
5. Noble, R. L., and Collip, J. B., Quantitative method for production of experimental traumatic shock without hemorrhage in unanesthetized animals. Quart. J. Exper. Physiol., 1942, 31, 187.

6. Manery, J. F., and Solandt, D. Y., Studies in experimental traumatic shock with particular reference to plasma potassium changes. Am. J. Physiol., 1942-43, 138, 499.

7. Peters, J. H., Determination of creatinine and creatine in blood and urine with photoelectric colorimeter. J. Biol. Chem., 1942, 146, 179.

8. Aub, J. C., and Wu, H., Studies in experimental traumatic shock. III : Chemical changes in the blood. Am. J. Physiol., 1920, 54, 416.

9. Bywaters, E. G. L., Crooke, A. C., and Morris, C. J. O. R., Limb compression in the tube shelter disaster, with note on plasma volume determinations. Lancet, 1943, 2, 373.

10. Aub, J. C., Brues, A. M., Dubos, R. J., Kety, S. S., Nathanson, I. T., Pope, A., and Zamecnik, P. C., Bacteria and the "toxic factor" in shock. War Med., 1944, 5, 71.

11. Pope, A., Zamecnik, P. C., Aub, J. C., Brues, A. M., Dubos, R. J., Nathanson, I. T., and Nutt, A. L., The toxic factors in experimental traumatic shock. VI. The toxic influence of the bacterial flora, particularly Clostridium welchii, in exudates of ischemic muscle. J. Clin. Invest., 1945, 24, 859.

12. Ashworth, C. T., and Kregel, L. A., Changes in body water partition and extracellular electrolyte in shock. Arch. Surg., 1942, 44, 829.

13. Clarke, A. P. W., and Cleghorn, R. A., Chemical study of tissue changes in adrenal insufficiency and traumatic shock. Endocrinology, 1942, 31, 597.

14. Nathanson, I. T., Nutt, A. L., Pope, A., Zamecnik, P. C., Aub, J. C., Brues, A. M., and Kety, S. S., The toxic factors in experimental traumatic shock. I. Physiologic effects of muscle ligation in the dog. J. Clin. Invest., 1945, 24, 829.

15. Leva, E., A colorimetric micromethod for the determination of sodium with manganous uranyl acetate. J. Biol. Chem., 1940, 132, 487.

16. Lowry, O. H., and Hastings, A. B., Histochemical changes associated with aging; methods and calculations. J. Biol. Chem., 1942, 143, 257.

17. Schales, O., and Schales, S. S., Simple and accurate method for determination of chloride in biological fluids. J. Biol. Chem., 1941, 140, 879.

18. Chesley, L. C., Determination of thiocyanate in biological fluids. J. Biol. Chem., 1941, 140, 135.

19. Cohn, W. E., Determination of hemoglobin in tissue extracts or other turbid solutions. J. Biol. Chem., 1943, 148, 219.

20. Hastings, A. B., and Eichelberger, L., Exchange of salt and water between muscle and blood; effect of increase in total body water produced by intravenous injection of isotonic salt solutions. J. Biol. Chem., 1937, 117, 73.
21. Muntwyler, E., Mellors, R. C., Mautz, F. R., and Mangun, G. H., Electrolyte and water equilibria in dog; electrolyte and water exchange between skeletal muscle and blood in adrenal insufficiency. J. Biol. Chem., 1940, 134, 367.

22. Engle, D., and Forrai, E., Capillary permeability in traumatic shock. J. Physiol., 1943, 102, 127.

23. Scudder, J., Smith, M. E., and Drew, C. R., Plasma potassium content of cardiac blood at death. Am. J. Physiol., 1939, 126, 337.

24. Kety, S. S., and Pope, A., The cardiovascular system in traumatic shock. Am. Heart J., 1944, 27, 601.

25. Aub, J. C., Brues, A. M., Kety, S. S., Nathanson, I. T., Nutt, A. L., Pope, A., and Zamecnik, P. C., The toxic factors in experimental traumatic shock. IV. The effects of the intravenous injection of the effusion from ischemic muscle. J. Clin. Invest., 1945, 24, 848.

26. Cannon, W. B., Traumatic Shock. D. Appleton and Co., New York, 1923.

27. Bayliss, W. M., Further observations on the results of muscle injury and their treatment. Reports of the Special Investigation Committee on Surgical Shock and Allied Conditions. Medical Research Council, London, 1919, p. 23.

28. Blalock, A., Experimental shock: the cause of the low blood pressure produced by muscle injury. Arch. Surg., 1930, 20, 959.

29. Blalock, A., Experimental shock. South. M. J., 1930, 23, 1013.

30. Blalock, A., Experimental shock. VI. The probable cause for the reduction in blood pressure following mild trauma to an extremity. Arch. Surg., 1931, 22, 598.

31. Parsons, E., and Phemister, D. B., Hemorrhage and "shock" in traumatized limbs; and experimental study. Surg., Gynec., Obst., 1930, 51, 196.

32. Mudd, S., and Thalhimer, W., Editors, Blood Substitutes and Blood Transfusions. Charles C. Thomas, Springfield, Ill., 1942, Chapter II. Solandt, D. Y., and Best, C. H.

33. Blalock, A., and Harrison, T. R., The regulation of the circulation. V. The effect of anaemia and hemorrhage on the cardiac output of dogs. Am. J. Physiol., 1927, 80, 157.

34. Govier, W. M., and Greer, C. M., Studies on shock induced by hemorrhage. I. The effect of thiamin on survival time. J. Pharmacol. and Exper. Therap., 1941, 72, 317.

35. Govier, W. M., and Greer, C. M., Studies on shock induced by hemorrhage. II. Effect of thiamin on disturbances of carbohydrate metabolism. J. Pharmacol. and Exper. Therap., 1941, 72, 321.

36. Johnson, G. S., and Blalock, A.; Experimental shock. IX. A study of the effects of the loss of whole blood, of blood plasma and of red blood cells. Arch. Surg., 1931, 22, 626. 
37. Price, P. B., Hanlon, C. R., Longmire, W. P., and Metcalf, W., Experimental shock; effects of acute hemorrhage in healthy dogs. Bull. Johns Hopkins Hosp., 1941, 69, 327.

38. Weston, R. E., Janota, M., Levinson, S. O., and Necheles, H., Hemoconcentration and shock following severe hemorrhage. Am. J. Physiol., 1943, $138,450$.

39. Blalock, A., Mechanism and treatment of experimental shock. I. Shock following hemorrhage. Arch. Surg., 1927, 15, 762.

40. Blalock, A., Shock; further studies with particular reference to effects of hemorrhage. Arch. Surg., 1934, 29, 837.

41. Magladery, J. W., Solandt, D. Y., and Best, C. H., Serum and plasma in treatment of haemorrhage in experimental animals. Brit. M. J., 1940, 2, 248.

42. Bell, J. R., Clark, A. M., and Cuthbertson, D. P., Experimental traumatic shock. J. Physiol., 1938, 92, 361.

43. Fender, F. A., and Guptill, P., A note on primary shock. Surg., Gynec., Obst., 1936, 62, 605.

44. McIver, M. A., and Haggart, W. W., Traumatic shock; some experimental work on crossed circulation. Surg., Gynec., Obst., 1923, 36, 542.

45. Kendrick, D. B., Jr., Essex, H. E., and Helmholz, H. F., Jr., Investigation of traumatic shock bearing on the toxemia theory. Surgery, 1940, 7, 753.

46. Freedman, A. M., and Kabat, H., The pressor response to adrenalin in the course of traumatic shock. Am. J. Physiol., 1940, 130, 620.

47. Mudd, S., and Thalhimer, W., Editors, Blood Substitutes and Blood Transfusions. Charles C. Thomas, Springfield, IIl., 1942, Chapter I. Cullen, M. L., Schecter, A. E., Freeman, N. E., and Laws, M. K.

48. Schecter, A. E., Cullen, M. L., and Freeman, N. E., Production of shock by trauma after spinal cord transection. Am. J. Physiol., 1942, 137, 710.

49. Freedlander, S. O., and Lenhart, C. H., Traumatic shock. Arch. Surg., 1932, 25, 693.

50. Herbst, R., Experimentalles zur Entstehung des traumatischen Shocks. Arch. f. Klin. Chir., 1933, 176, 98.

51. Perlow, S., Killian, S. T., Katz, L. N., and Asher, R., Shock following venous occlusion of the leg. Am. J. Physiol., 1941, 134, 755.

52. Cullen, M. L., and Freeman, N. E., Technique for measurement of local fluid loss in experimental traumatic shock. Surgery, 1941, 10, 770.

53. Seligman, A., Frank H., and Fine, J., Personal communication.

54. Keckwick, A., Marriott, H. L., Maycock, W. D'A., and Whitby, L. E. H., Diagnosis and treatment of secondary shock; a study of 24 cases. Lancet, 1941, $1,99$.

55. Kety, S. S., Nathanson, I. T., Nutt, A. L., Pope, A., Zamecnik, P. C., Aub, J. C., and Brues, A. M., The toxic factors in experimental traumatic shock. III. Shock accompanying muscle ischemia and loss of vascular fluid. J. Clin. Invest., 1945, 24, 842.
56. Vincent, S., and Sheen, W., Effects of intravenous injections of extracts of animal tissues. J. Physiol., 1903, 29, 242.

57. Stone, H. B., Bernheim, B. M., and Whipple, G. H., Intestinal obstruction, a study of toxic factors. Bull. Johns Hopkins Hosp., 1912, 23, 159.

58. Turck, F. B., Surgical shock. J. A. M. A., 1897, 28, 1160.

59. Cornioley, and Katzareff, Resumé de recherches experimentales et anatomopathiologiques sur la toxemie traumatique. Rev. de Chir., 1921, 59, 1.

60. Popielski, L., Uber die physiologische Wirkung von Extrakten aus sämtlichen Teilen des Verdaüungskanales, usw. Arch. f. d. ges. Physiol., 1909, 128, 191.

61. Delbet, P., and Karajonopoulos, De la toxicité des autolysats musculaires au point de vue du choc. Bull. Acad. de med., Paris, 1918, 80, 13.

62. Mason, E. C., Davidson, E. C., Matthew, C. W., and Rastello, P. B., A study of tissue autolysis in vivo. I. Blood changes: physical and chemical. J. Lab. and Clin. Med., 1925, 10, 622.

63. Moon, V. H., Shock, its Dynamics, Occurrence, and Management. Lea and Febiger, Philadelphia, 1942.

64. Green, H. N., Shock producing factor(s) from striated muscle; isolation and biological properties. Lancet, 1943, 2, 147.

65. Abraham, E. P., Brown, G. M., Chain, E., Florey, H. W., Gardner, A. L., and Sanders, A. G., Tissue autolysis and shock. Quart. J. Exper. Physiol., 1941, 31, 79.

66. Cournand, A., Riley, R. L., Bradley, S. E., Bried, E. G., Noble, R. P., Lanson, H. D., Gregerson, M. I., and Richards, D. W., Studies of the circulation in clinical shock. Surgery, 1943, 13, 964.

67. Blalock, A., Study of thoracic duct lymph in experimental crush injury and injury produced by gross trauma. Bull. Johns Hopkins Hosp., 1943, 72, 54.

68. Katzenstein, R., Mylon, E., and Winternitz, M. C., The toxicity of the thoracic duct fluid after release of tourniquets applied to the hind legs of dogs for the production of shock. Am. J. Physiol., 1943, 139, 307.

69. Roome, N. W., and Wilson, H., Experimental shockthe effects of extracts from traumatized limbs on the blood pressure. Arch. Surg., 1935, 31, 361.

70. Zamecnik, P. C., Aub, J. C., Brues, A. M., Kety, S. S., Nathanson, I. T., Nutt, A. L., and Pope, A, The toxic factors in experimental traumatic shock. V. Chemical and enzymatic properties of muscle exudate. J. Clin. Invest., 1945, 24, 853.

71. Aub, J. C., and Cunningham, T. D., Studies in experimental traumatic shock. II. The oxygen content of the blood. Am. J. Physiol., 1920, 54, 408.

72. Dumke, P. R., and Schmidt, C. F., Quantitative measurements of cerebral blood flow in the macacque monkey. Am. J. Physiol., 1942-43, 138, 421.

73. Grassmann, W., and Heyde, W., Alkalimetrische Mikrobestimmung der Aminosauren und Peptide. Ztschr. f. physiol. Chem., 1929, 183, 32. 
74. McMeekin, T. L., Serum albumin. I. The preparation and properties of crystalline horse serum albumin of constant solubility. J. Am. Chem. Soc., 1939, 61, 2884.

75. Aub, J. C., A toxic factor in experimental traumatic shock. New England J. Med., 1944, 231, 71.

76. Drinker, C. K., and Yoffey, J. M., Lymphatics, Lymph, and Lymphoid Tissue. Harvard University Press, Cambridge, Mass., 1941, Chapter 5, pp. 146-162.

77. Gamble, J. L., Chemical Anatomy, Physiology, and Pathology of Extracellular Fluid. Spaulding-Moss Co., Boston, 1941.

78. Flosdorf, E. W., and Mudd, S., Procedure and apparatus for preservation in "lyophile" form of serum and other biological substances. J. Immunol., 1935, 29, 389.

79. Herbert, D., Gordon, H., Subrahmanyan, V., and Green, D. E., Zymohexase. Biochem. J., 1940, 34, 1108.

80. Vernon, H. M., The ereptic power of tissues as a measure of functional capacity. J. Physiol., 1905, 33, 81.

81. Vernon, H. M., Intracellular Enzymes. John Murray, London, 1908.

82. Abderhalden, E., and Hunter, A., Weitere beiträge zur Kenntnis der Proteolytischen fermente der tierischen organe. Ztschr. f. physiol. Chem., 1906, 48, 537.

83. Schwimmer, S., Comparison of crude and purified preparations of a leucylpeptidase associated with beef muscle. J. Biol. Chem., 1944, 154, 361.

84. Smith, E. L., and Bergmann, M., The peptidases of intestinal mucosa. J. Biol. Chem., 1944, 153, 627.
85. Bergmann, M., Classification of proteolytic enzymes. Advances Enzymol., 1942, 2, 49.

86. Zamecnik, P. C., Stephenson, M. L., and Cope, O., Peptidase activity of lymph and serum after burns. J. Biol. Chem., 1945, 158, 135.

87. Trusler, H. M., and Reeves, J. R., Significance of anaerobic organisms in peritonitis due to liver autolysis; bacterial flora of liver and muscle of normal dogs. Arch. Surg., 1934, 28, 479.

88. Wilson, H., and Roome, N. W., The effects of constriction and release of an extremity. Arch. Surg., 1936, $32,334$.

89. Shwartzman, G., The Phenomenon of Local Tissue Reactivity. Paul Hoeber, New York, 1937.

90. Freedberg, A. S., and Lenobel, H. H., Personal communication to the authors.

91. Bull, C. G., and Pritchett, I. W., Identity of the toxins of different strains of Bacillus welchii and factors influencing their production in vitro. J. Exper. Med., 1917, 26, 867.

92. Kellaway, C. H., and Trethewie, E. R., Tissue injury by toxin of $\mathrm{Cl}$. welchii Type A. Australian J. Exper. Biol. and M. Sc., 1941, 19, 17.

93. Moon, V. H., Shock and related capillary phenomena. Oxford University Press, New York, 1938.

94. McLennan, J. D., Anaerobic infections of war wounds in Middle East. Lancet, 1943, 2, 63, 94, and 123.

95. Lyons, C., Penicillin therapy of surgical infections in the U. S. Army, J. A. M. A., 1943, 123, 1007.

96. Miles, A. A., and Miles, E. M., The fixation of foreign material in inflamed tissue, with especial reference to the action of $\mathrm{Cl}$. welchii toxin and antitoxin. Brit. J. Exper. Path., 1943, 24, 95. 